\title{
CHARACTERIZATION OF PAULOWNIA TOMENTOSA STEUD TREES GROWN IN A 5-YEAR-OLD PLANTATION IN COSTA RICA
}

\author{
JOSÉ DAVID SÁNCHEZ-MACHADO and ROGER MOYA \\ Instituto Tecnologico de Costa Rica, Escuela de Ingeniería Forestal, Cartago, Costa Rica \\ \orresponding author: R. Moya, rmoya@itcr.ac.cr
}

Received February 16, 2021

Paulownia tomentosa is utilized in Costa Rica and other countries for wood production and as feedstock for biomass, though the variation of wood properties for this species is scarcely known. In this work, the specific wood properties of a 5-year-old plantation in Costa Rica were studied. The results showed that bark and pith percentage and wood specific gravity (SG) increased with tree trunk height, while the proportion of heartwood, green wood density and green wood moisture content decreased. The average wood SG was 0.26 and tended to increase from pith to bark. Low wood SG values are related to low mechanical properties, with the advantage that wood shrinkage is low as well, which gives this wood species the potential to be utilized for reforestation purposes in Costa Rica. The gross calorific value of this species was $17809 \mathrm{~kJ} / \mathrm{kg}$, which, together with its cellulose and extractives contents, recommend $P$. tomentosa as a biomass source for energy production.

Keywords: kiri, tropical wood, fast growth, energy properties, wood characteristics

\section{INTRODUCTION}

Reforestation with commercial fast-growing species in Costa Rica started in the 1970s. ${ }^{1}$ To date, 15-20 native and exotic species are recommended for commercial reforestation. ${ }^{2,3}$ Growth trials on less common species, such as Paulownia, have been conducted, but knowledge of their properties is limited, which restricts their adequate use. ${ }^{1}$ Paulownia lumber can be used for furniture, handcrafts, musical instruments, ${ }^{4}$ and even biofuel production. ${ }^{5}$

$P$. tomentosa is native to China, where it grows in the central and northern regions; in the past, it was cultivated in Japan and South Korea, where it is known as "kiri". It was introduced as an ornamental species to European countries and the United States, and for wood production in Brazil, Paraguay, Argentina and Australia. ${ }^{5}$

In Costa Rica, there is a small business promoting the cultivation of this species for planting along property boundaries or to establish small plantations in the northern region. ${ }^{6}$ However, no data on its growth or wood properties are available as yet, which would reveal the characteristics and use potential of the wood of this genus. It is important to note that wood from commercial plantations presents a variety of uses, as the intrinsic characteristics of each species make it unique. ${ }^{7}$ These features determine the properties of the material that distinguish it from other products. ${ }^{8}$ Therefore, they must be determined and taken into account in the utilization of the wood and the quality of the final wood products desired. ${ }^{8}$

Density is considered an indicator of quality, and is highly correlated with mechanical properties, resistance and calorific power. ${ }^{9}$ Density varies considerably from the pith to the bark, especially in tropical fast-growing trees. ${ }^{10}$ Besides, if density profiles are determined, they can be employed to understand the growth dynamics in trees that do not present clear annual rings, as well as to define the management conditions in forest plantations and study the variability of wood quality.

Thus, the objective of this study has been to characterize the anatomical, physical, mechanical and chemical wood properties of 5-year-old Paulownia tomentosa trees grown in Costa Rica. In addition, the pith-bark density variation has been studied by means of X-ray densitometry to gather information regarding the appropriate 


\section{JOSÉ DAVID SÁNCHEZ-MACHADO and ROGER MOYA}

utilization of such wood, according to technical criteria.

\section{EXPERIMENTAL}

\section{Material provenance and plantation description}

Nine Paulownia tomentosa trees were chosen from a 5-year-old plantation in San Carlos, Alajuela, Costa Rica $\left(10^{\circ} 27^{\prime} 17,712\right.$ ' $\mathrm{N}$ and $\left.84^{\circ} 25^{\prime} 14,844^{\prime \prime} \mathrm{W}\right)$. The plantation had an initial spacing of 3 x $3 \mathrm{~m}$ (1100 $\mathrm{N} / \mathrm{ha}$ ). It had not been managed; therefore tree death occurred naturally only. The density of the plantation was of 813 trees/ha; average commercial height of 4.27 meters; average total height of $9.04 \mathrm{~m}$; and average diameter at 1.3 height $-14.83 \mathrm{~cm}$.

\section{Sampling}

Nine trees were randomly selected with the diameter similar to the average diameter of the plantation, previously obtained by measuring the diameters of the established plots. The cut trees had straight trunks, normal branching and no disease or pest symptoms. The commercial height - when the tree diameter is $10 \mathrm{~cm}$ - was measured for these trees. Sampling of the trees consisted in the extraction of cross-section discs and logs (Fig. 1a). Two sections were obtained from the logs: one from the base to breast height diameter (DBH) and the other from the $\mathrm{DBH}$ to $33.3 \%$ of the commercial height. As for the cross-section discs, these were $3.0 \mathrm{~cm}$ thick and were cut at the base, at DBH, as well as at 33.3\%, 66.67\% and $100 \%$ commercial height.

\section{Wood anatomy description}

A $1.2 \mathrm{~cm} \times 7.5 \mathrm{~cm} \times 12 \mathrm{~cm}$ sample was extracted for the macroscopic description of the wood (colour, sapwood and heartwood differentiation, texture, brightness, smell, taste, grain and density), using the terms mentioned in the IAWA List. ${ }^{11}$ Wood colour was determined based on the Munsell table, which is used to define soil colour. The Munsell colour system is a means to visually identify and match using a scientific approach. Three attributes of colour are defined: hue, value and chroma and the notation is: hue value/chroma.

Permanent slides were used for measuring the other anatomical characters. A description of the anatomical features was also made using the IAWA List as a guide. ${ }^{11}$ A cross-section ( $1.0 \mathrm{~cm}$ wide and $1.0 \mathrm{~cm}$ long) of the central stem was obtained. Wood samples were macerated using Franklin's method, and thin transversal, radial and tangential sections (permanent slides) about $10-15 \mu \mathrm{m}$ thick from the wood sample were cut using a microtome (Leica SM2000R). These sections were stained with safranin, and prepared as semi-permanent slides. ${ }^{12}$

\section{Determination of heartwood, sapwood and bark percentage}

For each cross-section from different heights, tree diameter, bark (thickness and total area percentage), pith (diameter and total area percentage) and heartwood (diameter and total area percentage) were determined.

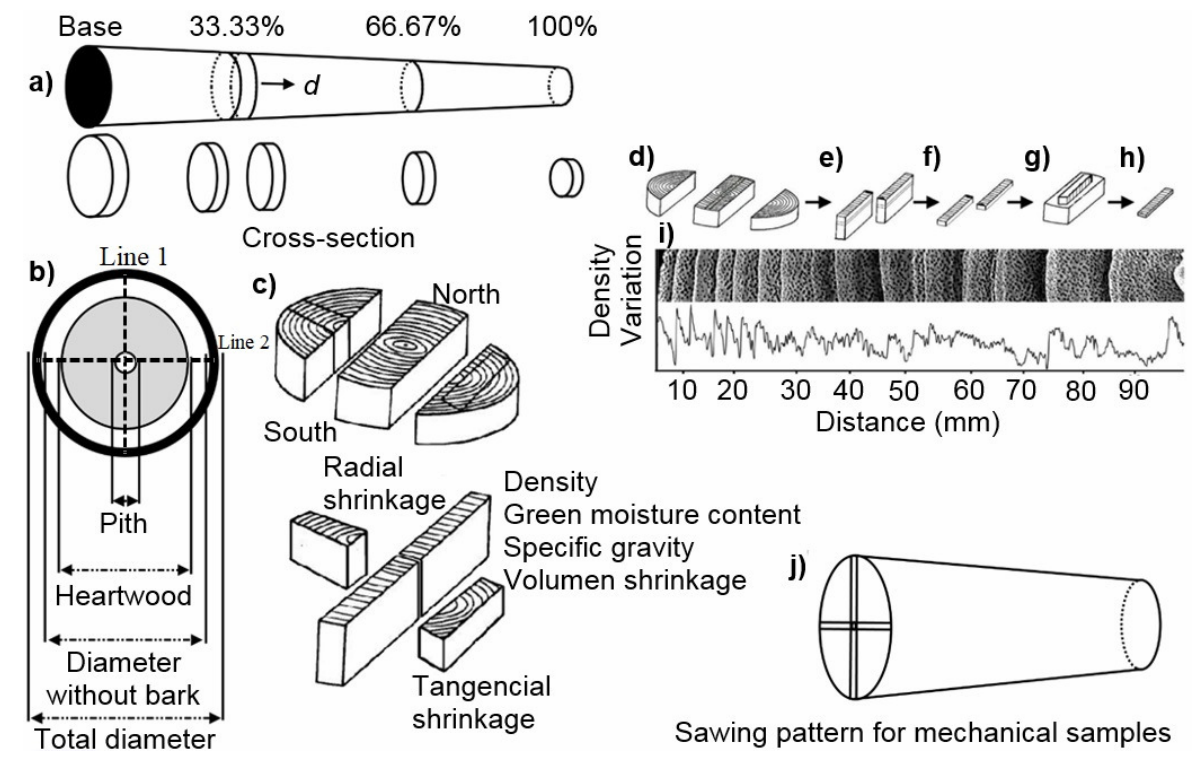

Figure 1: Sampled trees and sawing pattern used to determine wood properties: physical and mechanical properties (ac, j), thin sample for X-ray densitometry (d-h) and pith-bark density profile example (i) 
Two perpendicular lines (Line 1 and 2 in Fig. 1b) were drawn crossing the centre of each disc, one in the north-south direction and the other in the east-west direction. Total diameter, diameter without bark and pith and heartwood diameters were measured in both directions drawn on the disc. The percentages of bark, pith and heartwood were calculated relative to the area of these sections and the total disc area.

\section{Physical and mechanical properties}

The physical properties determined were green density, specific gravity (SG) and green moisture content (MC) in relation to oven-dried weight. These properties were determined in each disc taken from the trunk, for each percentage of commercial height $(0 \%$, $33.3 \%, 66.7 \%$ and $100 \%$ ). A $3.0 \mathrm{~cm}$-wide piece was cut from each cross-section, including the pith. The 3.0 cm-wide cross-section was cut into 2 pieces, the samples was divided at the pith (Fig. 1c). These samples were used to measure green density, density at $12 \% \mathrm{MC}$, oven-dried density, SG, SG at $12 \% \mathrm{MC}$ and $\mathrm{SG}$ in oven-dried condition. To determine the radial and tangential shrinkage (total and $12 \% \mathrm{MC}$ or normal shrinkage), two pieces (radial and tangential) were cut, with dimensions of $2.5 \mathrm{~cm} \times 2.5 \mathrm{~cm} \times 10 \mathrm{~cm}$. The density was calculated as the ratio of green weight/green volume, while SG, different shrinkages, $\mathrm{MC}$ and mechanical properties were calculated according to ASTM D-143. ${ }^{13}$ The $\operatorname{logs}$ obtained from the sampled trees were sawn (Fig. 1j) and the pieces were dried to obtain $12 \% \mathrm{MC}$ condition. For each of the mechanical tests, 18 samples were prepared for the assessment of each mechanical property as per ASTM D-143. ${ }^{13}$

\section{X-ray densitometry measurement and density profile}

In each of the cross-sections, a $4 \mathrm{~cm}$ wide sample was initially cut in the north-south direction (Fig. 1d). A $1 \mathrm{~cm}$ wide sample was then cut in the same direction, passing through the tree pith. This sample was separated at the pith to obtain a subsample in the north direction and a subsample south (Fig. 1f). A 1 $\mathrm{cm}$ thick piece was cut from each section. These subsamples were glued radially onto a wood support (Fig. 1g). The pieces were then cut with a double circular saw to extract $2 \mathrm{~mm}$ thick samples for the Xray densitometry thickness analysis (Fig. 1h). The thin wood samples were conditioned at $12 \% \mathrm{MC}$ in a chamber at $22{ }^{\circ} \mathrm{C}$ and $66 \%$ relative humidity. The $\mathrm{X}$ ray densitometry measurement was performed in the transverse direction (Fig. 1d-h). Sample exposure was performed using an X-ray scanner from Quintek Measurement Systems Inc. (model QTRS-01X) at 7 $\mathrm{kV}$ tension in the tube, and the density readings were carried out every $80 \mu \mathrm{m}$. The actual density of each thin sample was previously determined by weighing it with a precision scale, and measuring its length, height and thickness to calculate the volume.

\section{Chemical composition and energy properties}

The cellulose, lignin, ash and extractive contents in hot and cold water, in ethanol with toluene, dichloromethane and sodium hydroxide $(\mathrm{NaOH})$, as well as the contents of carbon $(\mathrm{C})$, hydrogen $(\mathrm{H})$, nitrogen $(\mathrm{N})$ and sulphur $(\mathrm{S})$, were determined. The contents of macro- and micro-elements contained in the ashes, volatiles and the gross calorific values were measured. Three samples were used for determining these properties according to the following standards: method T222 om- $02^{14}$ for lignin content; Seifert ${ }^{15}$ for cellulose; ASTM D1110-84 ${ }^{16}$ for extractives in water (hot and cold conditions); ASTM D 1109-84 for $\mathrm{NaOH} ;{ }^{17}$ ASTM D1107-96 for the ethanol-toluene solution; ${ }^{18}$ ASTM D1108-96 ${ }^{17}$ for $\mathrm{CH}_{2}-\mathrm{Cl}_{2} ;{ }^{17}$ ASTM D1102-84 standard $^{19}$ for ash content and ASTM D5865 standard $^{20}$ for determination of the gross calorific values. A CHNS Vario El cube series 19171074 was utilized for determining the mass of $\mathrm{C}, \mathrm{H}, \mathrm{N}$ and $\mathrm{S}$.

\section{Data analysis}

The data collected were processed with Excel software. For the anatomical features, their average, minimum and maximum values, standard deviation and coefficient of variation were calculated. The average, standard deviation and coefficient of variation were obtained for the physical, mechanical and chemical properties. The tissue characteristics were processed as percentages with their corresponding standard deviation, shown in box-plot graphs with a linear trend line, together with three physical properties, the average density variation and the coefficient of variation between these values and the distance from the pith.

\section{RESULTS AND DISCUSSION General description of the wood}

$P$. tomentosa wood presented a slight differentiation between the sapwood and the heartwood (Fig. 2a). The colour of heartwood in air-dried condition was pinkish white $(7.5 \mathrm{YR} 8 / 2)$ and that of sapwood was white (7.5YR 8/1). There were no streaks; any smell and taste were imperceptible; brightness was imperceptible to moderate and growth rings were not strongly marked (Fig. 2c).

\section{Wood macroscopic description}

Vessels were slightly visible to the naked eye, wood presented diffuse porosity with slight formation of small oblique or diagonal bands (Fig. 2b). Axial parenchyma was visible to the naked eye, of the type abundant vasicentric 


\section{JOSÉ DAVID SÁNCHEZ-MACHADO and ROGER MOYA}

paratracheal and lozenge to confluent (Fig. 3a). Radial parenchyma was visible with $10 \mathrm{X}$ magnification (Fig. 2b) and the rays were nonstoried, narrow and with low frequency.

\section{Wood microscopic description}

Pores: the wood presented diffuse porosity and the pores were distributed in oblique or diagonal bands, with single pores and multiple radials (Fig. 1b). The pore frequency averaged 2.23 vessels $/ \mathrm{mm}^{2}$ (minimum: 1.92, maximum: 2.69 vessels $/ \mathrm{mm}^{2}$ ), with a length of $160.20 \mu \mathrm{m}$ (minimum: $85.42 \mu \mathrm{m}$, maximum: $275.55 \mu \mathrm{m}$ ) and average diameter of $140.18 \mu \mathrm{m}$ (minimum: 74.27 $\mu \mathrm{m}$, maximum: $184.95 \mu \mathrm{m})$. The vessels had long appendages at one end with single perforation plates; no gums or tyloses were observed. Intervascular pits were hexagonal, alternatively distributed (Fig. 2c), vessel-ray pits were with distinct borders; similar to inter-vessel pits in size and shape throughout the ray cell, or rounded or angular pits (Fig. 2d).
Fibers: fusiform cells were observed, nonseptate, with an average length of $872.07 \mu \mathrm{m}$ (minimum: $425.67 \mu \mathrm{m}$, maximum: $1129.85 \mu \mathrm{m}$ ), average diameter of $28.90 \mu \mathrm{m}$ (minimum: 15.15 $\mu \mathrm{m}$, maximum: $40.26 \mu \mathrm{m})$; average lumen diameter was $21.66 \mu \mathrm{m}$ (minimum: $7.51 \mu \mathrm{m}$, maximum: $31.94 \mu \mathrm{m}$ ), without crystals. Fibres presented simple to minutely bordered pits.

Radial parenchyma: rays were formed by procumbent cells, homocellular and non-storied. The rays were from 1-3 and 4-10 serial in width, averaged a height of $320.19 \mu \mathrm{m}$ (minimum: $168.07 \mu \mathrm{m}$, maximum $576.50 \mu \mathrm{m}$ ) and a width of 47.26 $\mu \mathrm{m}$ (minimum: $29.66 \mu \mathrm{m}$, maximum: 63.96 $\mu \mathrm{m}$ ). The number of cells was 18.64 (minimum: 9, maximum: 33 ) in height and 4.8 cells in width (minimum: 4, maximum: 6) and two sizes of rays.

Axial parenchyma: paratracheal parenchyma was aliform, lozenge-aliform, winged-aliform and confluent and parenchyma was in marginal or in seemingly marginal bands. Parenchyma was formed by fusiform cells, of two to four cells (34) per parenchyma strand.
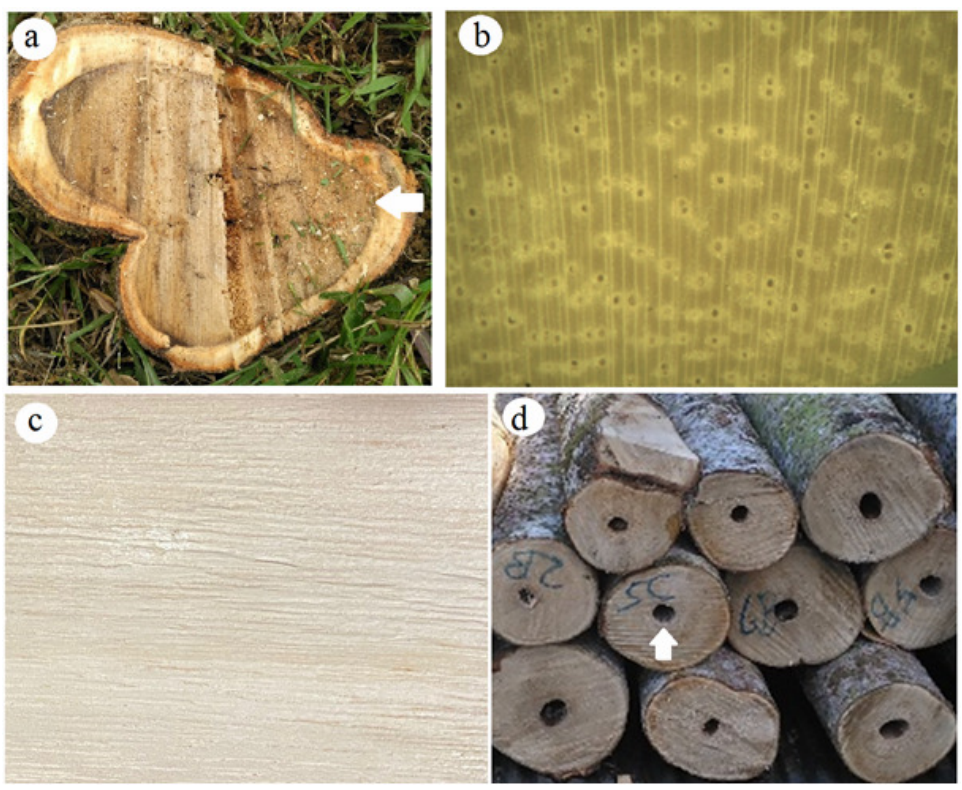

Figure 2: Cross-section of Paulownia tomentosa from basal part (a), macroscopic cross-section (b), tangential section (c) and pith presence with large diameter (d) (white arrow in (a) indicates heartwood-sapwood boundary, and in (d) the large diameter in relation to total diameter) 

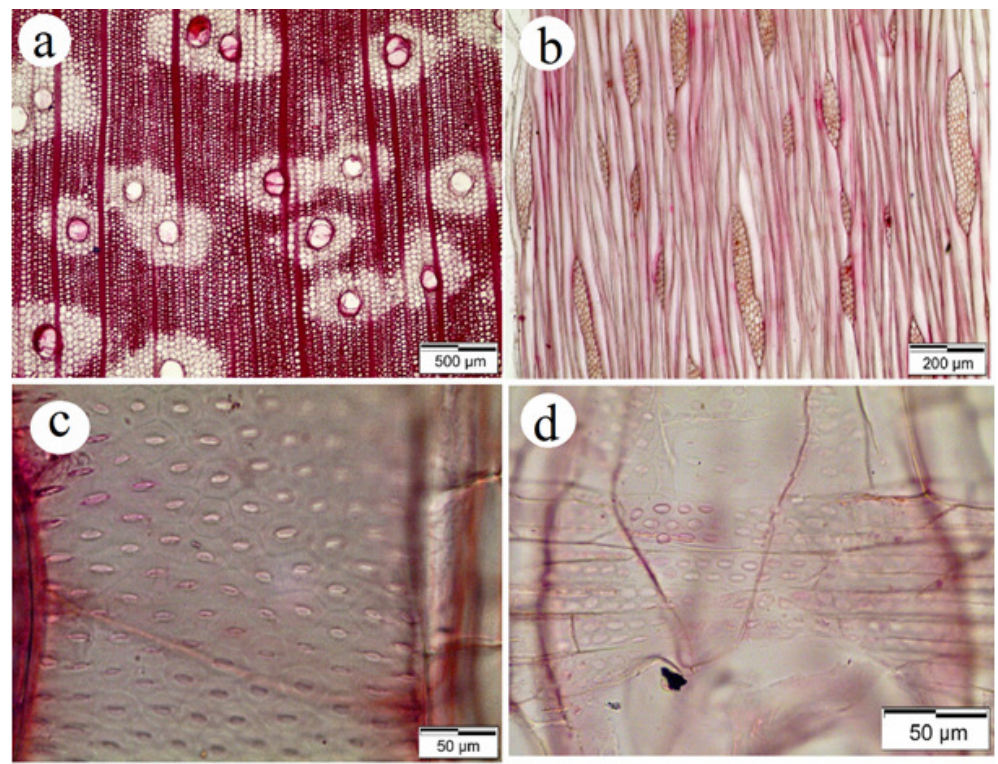

Figure 3: Anatomy of Paulownia tomentosa wood: (a) cross-section, (b) tangential section, (c) intervascular hexagonal pits, (d) vessel-rays pitting with much reduced borders to apparently simple: rounded or angular pits

\section{Physical properties and tree tissues variation}

The physical properties at breast height are presented in Table 1. Figure 4 shows the variations in heartwood, bark and pit percentages, SG, green MC and green density. SG presented a low result (0.26), therefore the wood sample was categorized as very light wood according to the classification of Hess et al. ${ }^{21}$ which established a range between 0.25 and 0.30 for this category.

It should be made clear that this low value of SG is influenced by the young age of the sampled trees (5 years). SG tended to increase close to the pith and decreased near the bark. In general, for many species, an increase in basic density occurs with tree age or in bark-pith direction. ${ }^{9}$ This change due to tree aging are explained by modifications produced in the woody cells. ${ }^{22}$

With reference to other properties of this wood, there are two aspects to highlight: (i) high green MC (approximately 285\%) and low values for the various types of shrinkage. In general, these are classified as low and very low. The green $\mathrm{MC}$ is important to determine the drying process parameters required by this species. Moya and Muñoz ${ }^{23}$ noted that species with high green $\mathrm{MC}$ are undesirable because of their long drying time. This has been also proven by Tenorio et $a l .^{24}$ in a drying study conducted on different tropical species. These authors found that species with high green $\mathrm{MC}$ had the lowest drying rates and the longest drying times. However, the drying behaviour of $P$. tomentosa should be still investigated in order to find out whether it really presents a prolonged drying time and if this species is prone to drying defects.

Shrinkage parameters are important in secondary processing of wood, such as in manufacturing furniture. ${ }^{25}$ Low values of volumetric shrinkage (Table 1), as well as tangential and radial shrinkage, are desirable to avoid dimensional distortion, warps and cracks, and are associated with good wood quality. ${ }^{25}$ Therefore, the low values of shrinkage found in $P$. tomentosa indicate that this species can be employed in the production of furniture. Moya and Muñoz $^{23}$ indicated different criteria for anisotropy and mentioned that when the $T / R$ shrinkage ratio varies from 1.5 to 2.0 , the wood is classified as of medium dimensional stability, and thus it is recommended for furniture production, due to low dimensional distortion. Then, according to this classification, $P$. tomentosa wood from plantations in Costa Rica is considered to have low to medium dimensional stability and can be used to produce furniture. 


\section{JOSÉ DAVID SÁNCHEZ-MACHADO and ROGER MOYA}

Table 1

Density, specific gravity, initial moisture content, calorific value and shrinkage of Paulownia tomentosa wood

\begin{tabular}{|c|c|c|c|c|c|}
\hline \multicolumn{6}{|c|}{ Wood density and specific gravity } \\
\hline Parameter & Initial condition & Air-drie & ition & & ried condition \\
\hline Wood density $\left(\mathrm{g} / \mathrm{cm}^{3}\right)$ & $0.99(9.2)$ & 0.29 & & & $28(10.7)$ \\
\hline Specific gravity & $0.26(11.0)$ & 0.27 & & & $28(10.7)$ \\
\hline \multicolumn{6}{|c|}{ Initial moisture content } \\
\hline Parameter & \multicolumn{2}{|c|}{ Green condition } & \multicolumn{3}{|c|}{ Oven-dried condition } \\
\hline Green moisture content (\%) & \multicolumn{2}{|c|}{$285.0(23.6)$} & \multicolumn{3}{|c|}{--} \\
\hline \multicolumn{6}{|c|}{ Wood shrinkage } \\
\hline \multirow{2}{*}{ Parameter } & \multicolumn{2}{|c|}{ Normal (Green-12\%) } & \multicolumn{3}{|c|}{ Total (Green-0\%) } \\
\hline & Value & Classification & & & Classification \\
\hline Radial shrinkage $(\%)$ & $1.58(63.5)$ & Very low & 2.09 & & Very low \\
\hline Tangential shrinkage $(\%)$ & $2.09(27.6)$ & Very low & 3.71 & & Low \\
\hline Volumetric shrinkage (\%) & $3.86(37.9)$ & Very low & 5.99 & & Low \\
\hline $\mathrm{T} / \mathrm{R}$ shrinkage ratio & $1.89(68.9)$ & Low & 2.13 & & High \\
\hline
\end{tabular}

*Numbers in parenthesis represent coefficient of variation
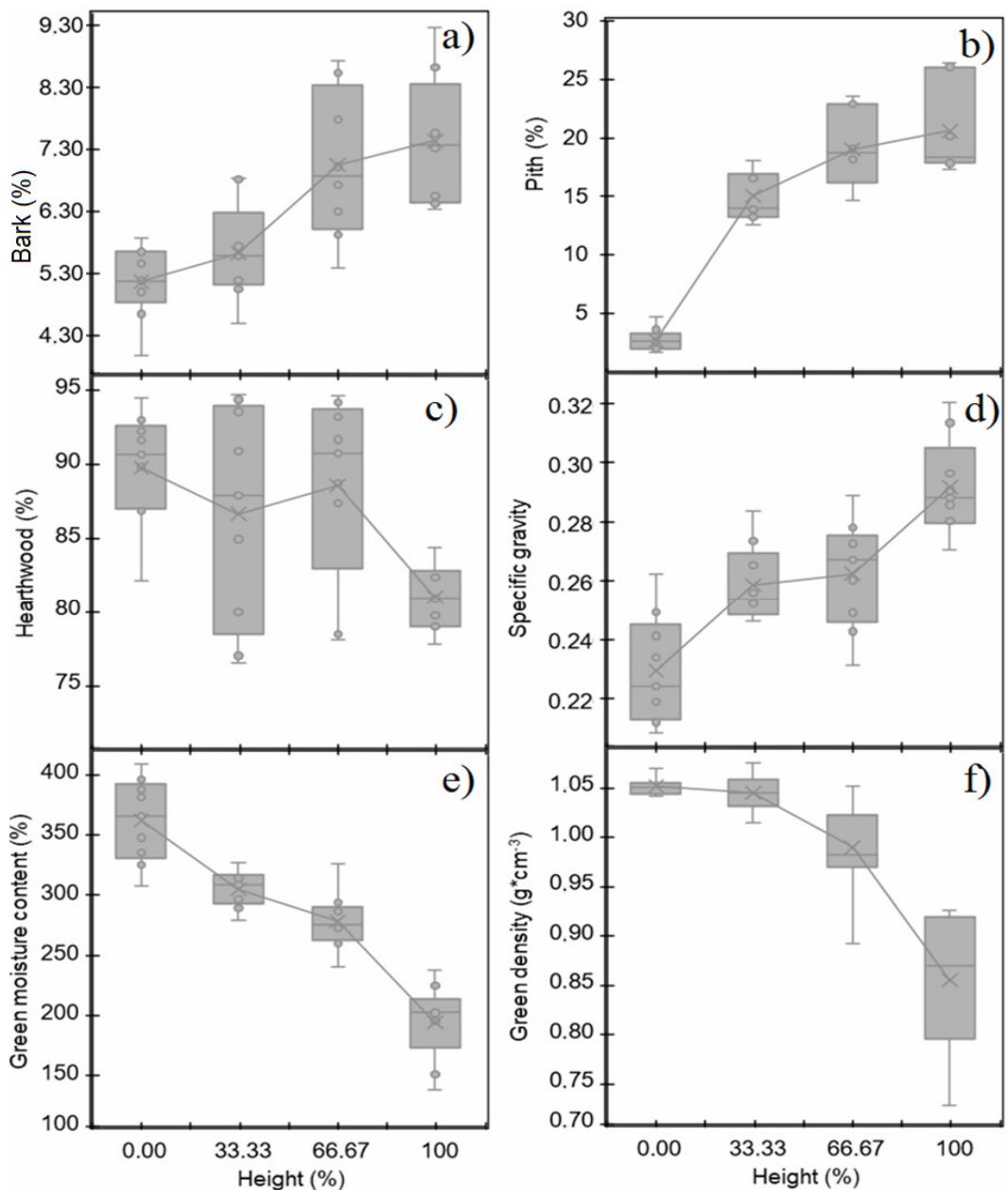

Figure 4: Relationship between bark, pith and heartwood proportions, specific gravity, green moisture content and green density with stem height (the box represents the $95 \%$ confidence interval, the center of the box - mean value, the lines $-99 \%$ confidence interval 

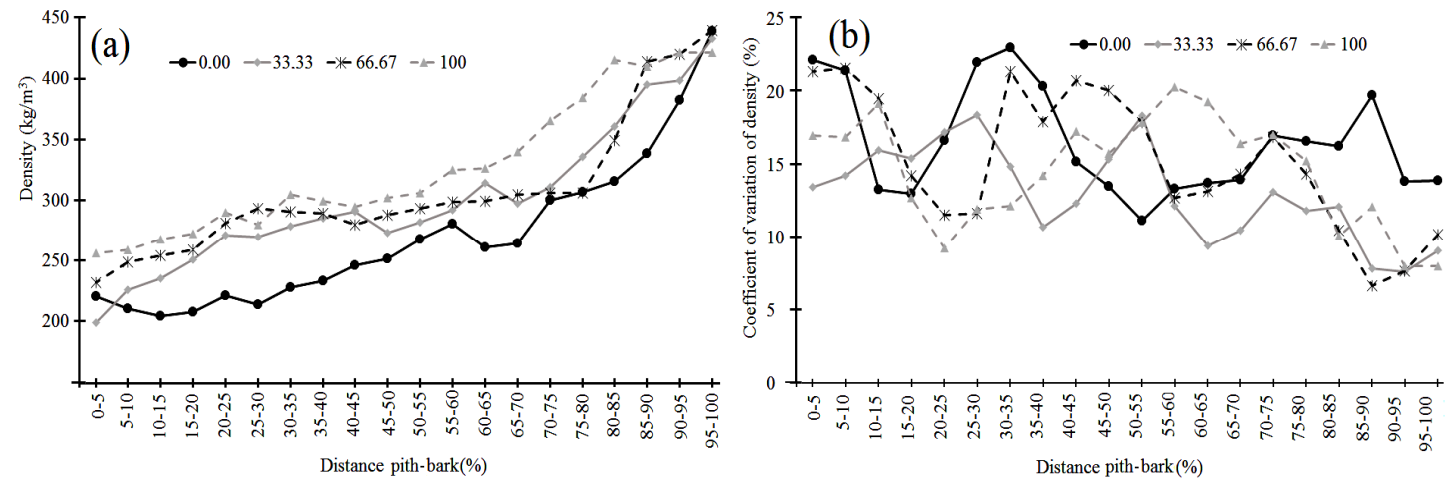

Figure 5: Density profile (a) and coefficient of variation of wood density (b) measured by X-ray densitometry for four tree heights

\section{General and physical properties variation with height}

Heartwood percentage decreased with height (Fig. 4c). Such a decrease is related to variations in the physiological processes occurring in trees. ${ }^{26}$ Heartwood originates from the death of the parenchyma and accumulation of substances (extractives) in the inner part of the tree. ${ }^{27}$ This behaviour varies with the height of the trees, ${ }^{26}$ resulting in a conic-shaped heartwood in the inner part of the tree. Thus, the heartwood's volume decreases with increasing stem height inside the tree (diameter and percentage), as happened in the Paulownia trees in the present study (Fig. 4c).

Bark percentage increased with increasing height, being less than $5.3 \%$ at the base of the stem and up to $7.3 \%$ at $100 \%$ commercial height (Fig. 4a). The bark is the tissue that protects the trees and, generally, it decreases along the stem height. ${ }^{28}$ Nevertheless, such behaviour was not observed in the present study, where bark percentage increased with tree height (Fig. 4a), as bark thickness remained constant at different tree heights. An increase in bark percentage can be observed in wood species used in commercial reforestation programs for sawlog production. ${ }^{23,24}$

Pith percentage increased from $3 \%$ to $10 \%$ as tree height increased (Fig. 4b). This is considered a drawback when industrializing the logs, since high pith percentage values diminish the quality and quantity of wood for sawing in the future, resulting in a lower recovery factor of wood. ${ }^{1}$ Therefore, special care should be given to this species due to its considerable pith diameter (Fig. 1d).

SG increased in direct proportion with tree height, varying from 0.230 at the base of the tree to over 0.290 at $100 \%$ height (Fig. 3d). This is an uncommon behaviour in trees, ${ }^{9}$ but it has been observed in other plantation species in Costa Rica as well. ${ }^{23,29}$ This behaviour has been attributed to physiological processes occurring in trees. ${ }^{26}$ When the physiological processes increase in the high section of the tree, physical space is reduced and therefore water availability also declines, resulting in the decrease of other parameters related to the quantity of water, such as green density and green moisture content. Green moisture content (Fig. 4e) and green density (Fig. 4f) decreased with increasing tree height.

\section{Bark-pith density variation}

Figure 5 illustrates the proportional variation of the density of $P$. tomentosa with the bark-pith distance, measured by means of X-ray densitometry, and the corresponding coefficient of variation. In general, the density value increased from the bark to the pith. ${ }^{9}$ The X-ray technique confirmed that the density decreased with height; at $0 \%$ height, lower values were revealed, in contrast to the density curve at $100 \%$ of the height, while similarities between both curves were observed between the different heights. Fluctuations in density, measured by the coefficient of variation, were predominant, therefore no clear trend in this parameter was evidenced (Fig. 5b).

In trees, the density tended to increase close to the bark and decreased when approaching the pith, ${ }^{30}$ as observed in Paulownia trees in this study (Fig. 5a). In general, for many species, an increase in density occurs with tree age or in pithbark direction, ${ }^{31}$ but the reason for this is not fully understood since the changes are related to the 


\section{JOSÉ DAVID SÁNCHEZ-MACHADO and ROGER MOYA}

species' growth strategy. ${ }^{32}$ This change can be explained by tree aging, modifications in the woody cells and cambial activity, which adds new wood toward the outer part of the tree. ${ }^{32}$ The variability of density reflects changes in environmental conditions, the demands of an aging tree and an increase in diameter. Therefore, the increase in density with height (Fig. 4f) and over the distance between the pith and the bark (Fig. 5a) is not clearly defined, this behaviour varying among species. ${ }^{9}$

\section{Mechanical and physical properties}

Table 2 shows the mechanical and chemical properties of $P$. tomentosa trees grown in a pure 5 -year-old plantation. The evaluation of the properties helps to make decisions regarding the different uses intended for this wood in the industry, among which is light construction. ${ }^{33}$ The results obtained in this study for plantation-grown $P$. tomentosa reveals their possible use for such purpose. According to the results obtained for mechanical properties, it could be classified as a low resistance wood, unsuitable for structural uses, ${ }^{4}$ but which can be used in construction in general. These results are congruent with those reported for this species in different regions of the world. ${ }^{34,35}$

Compared to $P$. tomentosa, the other 7 wood species utilized in commercial reforestation in Costa Rica (Table 3) present higher SG. ${ }^{38}$ However, all those woods were extracted from older plantations. Therefore, an increase in SG with age is to be expected in $P$. tomentosa as well, as has been observed, thus expanding the possibilities for its utilization. ${ }^{36}$

Because of the low value of $\mathrm{SG}$ in $P$. tomentosa, most of its mechanical properties were inferior to those of the rest of the species, except for Bombapcosis quinata whose properties were similar (Table 3). The latter species is used for making blockboards and furniture. ${ }^{29}$ Nevertheless, an advantage of this species is its lower tangential, radial and volumetric shrinkage values (Table 3), which is relevant in the drying and product making processes.

Table 2

Averages of mechanical, chemical and energy properties of Paulownia tomentosa wood

\begin{tabular}{|c|c|c|c|}
\hline Wood properties & \multicolumn{2}{|c|}{ Parameters } & Values \\
\hline \multirow{12}{*}{ Mechanical } & \multicolumn{2}{|c|}{ Stress in compression parallel to grain $\left(\mathrm{kg} / \mathrm{cm}^{2}\right)$} & $103.4(17.7)$ \\
\hline & \multicolumn{2}{|c|}{ Stress in compression perpendicular to grain $\left(\mathrm{kg} / \mathrm{cm}^{2}\right)$} & $169.6(19.2)$ \\
\hline & \multicolumn{2}{|c|}{ Stress in tension parallel to grain $\left(\mathrm{kg} / \mathrm{cm}^{2}\right)$} & $372.5(12.6)$ \\
\hline & \multicolumn{2}{|c|}{ Stress in tension perpendicular to grain $\left(\mathrm{kg} / \mathrm{cm}^{2}\right)$} & $11.7(28.7)$ \\
\hline & \multirow{2}{*}{ Static bending } & $\operatorname{MOR}\left(\mathrm{kg} / \mathrm{cm}^{2}\right)$ & $97.4(19.8)$ \\
\hline & & $\operatorname{MOE}\left(\mathrm{kg} / \mathrm{cm}^{2}\right)$ & $25329.8(19.5)$ \\
\hline & $\begin{array}{l}\text { Stress in shear parallel to grain } \\
\left(\mathrm{kg} / \mathrm{cm}^{2}\right)\end{array}$ & Tangential & $51.2(10.0)$ \\
\hline & Stress in cleavage $\left(\mathrm{kg} / \mathrm{cm}^{2}\right)$ & Tangential & $3.5(16.7)$ \\
\hline & \multirow{2}{*}{ Janka hardness $(\mathrm{kg})$} & Axial & $145.6(17.3)$ \\
\hline & & Lateral & $82.8(29.6)$ \\
\hline & \multirow{2}{*}{ Nail extraction $(\mathrm{kg})$} & Axial & $14.7(19.9)$ \\
\hline & & Lateral & $23.4(29.2)$ \\
\hline \multirow{12}{*}{ Chemical } & \multirow{3}{*}{ Global composition } & Cellulose $(\%)$ & $45.25(0.1)$ \\
\hline & & Lignin $(\%)$ & $18.64(2.4)$ \\
\hline & & Ash content $(\%)$ & $0.00(12.1)$ \\
\hline & \multirow{4}{*}{ Ash chemical composition } & Nitrogen $(\%)$ & $0.11(14.3)$ \\
\hline & & Carbon $(\%)$ & $46.3(0.4)$ \\
\hline & & Hydrogen $(\%)$ & $6.5(0.7)$ \\
\hline & & Sulfur $(\%)$ & $0.01(22.7)$ \\
\hline & \multirow{5}{*}{ Extractives soluble in } & $\mathrm{NaOH}$ at $1 \%(\%)$ & $16.0(1.0)$ \\
\hline & & Hot water $(\%)$ & $11.30(1.9)$ \\
\hline & & Cool water $(\%)$ & $16.0(4.8)$ \\
\hline & & Dichloromethane (\%) & $4.0(31.7)$ \\
\hline & & Ethanol-Toluene (\%) & $9.9(11.2)$ \\
\hline Energy & & Gross calorific value $(\mathrm{kJ} / \mathrm{kg})$ & $17809.4(5.3)$ \\
\hline Other properties & & $\mathrm{pH}$ & $4.9(2.0)$ \\
\hline
\end{tabular}

Numbers in parenthesis represent coefficient of variation 
Table 3

Comparison of physical and mechanical properties between $P$. tomentosa and seven tropical wood species grown in commercial plantations in Costa Rica ${ }^{38}$

\begin{tabular}{|c|c|c|c|c|c|c|c|c|c|}
\hline Properties & Wood parameter & $\begin{array}{c}P . \\
\text { tomentosa }\end{array}$ & $\begin{array}{c}\text { Alnus } \\
\text { acuminata }\end{array}$ & $\begin{array}{c}\text { Bombapcosis } \\
\text { quinata }\end{array}$ & $\begin{array}{c}\text { Cordia } \\
\text { alliodora }\end{array}$ & $\begin{array}{l}\text { Enterolobium } \\
\text { cyclocarpum }\end{array}$ & $\begin{array}{l}\text { Gmelina } \\
\text { arborea }\end{array}$ & $\begin{array}{c}\text { Vochysia } \\
\text { ferruginea }\end{array}$ & $\begin{array}{c}\text { Vochysia } \\
\text { guatemalensis }\end{array}$ \\
\hline Tree age & & 5 & 9 & 15 & 14 & 20 & 12 & 8 & 8 \\
\hline \multirow{6}{*}{$\begin{array}{l}\text { Physical } \\
\text { properties }\end{array}$} & Specific gravity & 0.26 & 0.34 & 0.32 & 0.39 & 0.35 & 0.40 & 0.37 & 0.32 \\
\hline & Green density $\left(\mathrm{g} / \mathrm{cm}^{3}\right)$ & 0.99 & 0.67 & 0.96 & 0.84 & 0.93 & 1.04 & 0.93 & 0.88 \\
\hline & Total radial shrinkage $(\%)$ & 2.09 & 4.11 & 2.45 & 4.01 & 1.67 & 5.39 & 5.52 & 2.75 \\
\hline & Total tangential shrinkage $(\%)$ & 3.71 & 6.31 & 3.18 & 5.89 & 2.59 & 7.00 & 5.97 & 7.38 \\
\hline & Total volume shrinkage $(\%)$ & 5.99 & 11.01 & 6.28 & 11.65 & 5.39 & 10.28 & 12.04 & 12.70 \\
\hline & $\mathrm{T} / \mathrm{R}$ shrinkage ratio & 2.13 & 1.62 & 1.34 & 1.57 & 1.67 & 1.42 & 1.21 & 2.69 \\
\hline \multirow{12}{*}{$\begin{array}{l}\text { Mechanical } \\
\text { properties }\end{array}$} & Compression // to grain $\left(\mathrm{kg} / \mathrm{cm}^{2}\right)$ & 103.4 & 340 & 87 & 274 & 214 & 318 & 245 & 213 \\
\hline & Compression $\perp$ to grain $\left(\mathrm{kg} / \mathrm{cm}^{2}\right)$ & 169.6 & 240 & 107 & 118 & 217 & - & 151 & 145 \\
\hline & Tension // to grain $\left(\mathrm{kg} / \mathrm{cm}^{2}\right)$ & 372.5 & 897 & 430 & 492 & 365 & 447 & 506 & 394 \\
\hline & Tension $\perp$ to grain $\left(\mathrm{kg} / \mathrm{cm}^{2}\right)$ & 11.7 & 28 & 10 & 41 & 29 & - & 52 & 16 \\
\hline & MOR in static bending $\left(\mathrm{kg} / \mathrm{cm}^{2}\right)$ & 97.4 & 784 & 358 & 737 & 313 & 503 & 767 & 404 \\
\hline & MOE in static bending $\left(\mathrm{kg} / \mathrm{cm}^{2} \times 10^{3}\right)$ & 25.3 & 123 & 55 & 53 & 30 & 83 & 59 & 64 \\
\hline & Stress in shear // to grain $\left(\mathrm{kg} / \mathrm{cm}^{2}\right)$ & 51.2 & 99 & 53 & 125 & 85 & 63 & 98 & 69 \\
\hline & Cleavage $\left(\mathrm{kg} / \mathrm{cm}^{2}\right)$ & 3.5 & 5 & 3 & 6 & 5 & - & 6 & 8 \\
\hline & Axial Janka hardness (kg) & 145.6 & 398 & 157 & 395 & 448 & 285 & 420 & 184 \\
\hline & Lateral Janka hardness $(\mathrm{kg})$ & 82.8 & 290 & 100 & 341 & 327 & 271 & 312 & 103 \\
\hline & Axial nail extraction $(\mathrm{kg})$ & 14.7 & 23 & 17 & 47 & 34 & - & 47 & 19 \\
\hline & Lateral nail extraction $(\mathrm{kg})$ & 23.4 & 31 & 20 & 63 & 44 & - & 55 & 20 \\
\hline
\end{tabular}

Note: R/T Ratio: ratio of shrinkage between tangential and radial shrinkage; // = parallel to fiber, $\perp=$ perpendicular to fiber 


\section{JOSÉ DAVID SÁNCHEZ-MACHADO and ROGER MOYA}

\section{Chemical properties and extractives}

The chemical properties, gross calorific value and $\mathrm{pH}$ of $P$. tomentosa grown in Costa Rica are detailed in Table 2. The chemical composition of the wood has important effects on the pulping process and for its use as an energy source. ${ }^{37}$ The results obtained in this work revealed adequate percentages of cellulose, lignin, carbon content, low content of ashes and extractives, recommending $P$. tomentosa as a potential species for energy production, according to a comparison of values reported by Yadav et $a .^{5}$ The gross calorific value was similar to that of species used in short rotation wood crops and other species commonly used in commercial reforestation. ${ }^{29}$ The results obtained explain why in recent years this species has gained importance as a potential source of energy. ${ }^{5}$

\section{CONCLUSION}

The wood of Paulownia tomentosa grown in fast-growing plantations in Costa Rica presented variations in properties related to the height and radial position of the tree, which can have possible future implications for the industrial processing of wood, because of the lack of uniformity of properties. It has been also observed that the wood has low specific gravity, which causes low mechanical properties, limiting its structural uses. Likewise, this wood species is only comparable to Bombapcosis quinatum wood, which is also used in commercial reforestation in Costa Rica, and is employed to manufacture blockboards. However, an advantage observed in the wood of Paulownia tomentosa is that it presents potential for energy production due to its high cellulose content, low ash content and low content of extractives in different solvents.

ACKNOWLEDGEMENTS: The authors wish to thank the Vicerrectoría de Investigación y Extensión at the Instituto Tecnológico de Costa Rica (ITCR). The authors also thank María Teresa Vargas L. for translating and editing the manuscript.

\section{REFERENCES}

1 R. Serrano and R. Moya, Rev. For. Mesoam. Kurú, $\quad 8, \quad 1 \quad$ (2011), https://revistas.tec.ac.cr/index.php/kuru/article/view 1370

2 R. Moya, Ambientico, 267, 32 (2018), https://www.ambientico.una.ac.cr/revista- ambientico/la-produccion-de-madera-de-especiesnativas-en-plantaciones-comerciales-una-opcionreal/

3 O. Murillo, Ambientico, 267, 4 (2018), https://www.ambientico.una.ac.cr/revistaambientico/cuales-especies-forestales-nativasdebemos-priorizar-en-el-pais/

4 M. H. Akyildiz and H. S. Kol, J. Environ. Biol., 31, 351

(2010),

http://www.jeb.co.in/journal_issues/201005_may10 /paper_21.pdf

N. K. Yadav, B. N. Vaidya, K. Henderson, J. F. Lee, W. M. Stewart et al., Am. J. Plant Sci., 4, 2070 (2013), https://doi.org/10.4236/ajps.2013.411259

6 J. Méndez and L. F. Obando, Ambientico, 267, 23

https://www.ambientico.una.ac.cr/pdfs/art/ambienti co/267_23-27.pdf

7 S. Suresh-Ramanan, T. K. Kunhamu, E. V. Anoop and A. K. George, J. Trop. Agric., 56, 137 (2018),

http://www.jtropag.kau.in/index.php/ojs2/article/vie w/572

8 C. Richter, in "Wood Characteristics: Description, Causes, Prevention, Impact on Use and Technological Adaptation", edited by C. Richter, Springer International Publishing, New York, USA, 2015, pp. 29-32, https://doi.org/10.1007/978-3-31907422-1_4

9 B. J. Zobel and J. P. van Buijtenen, in "Wood Variation: Its Causes and Control", Springer Verlag, Netherlands, 1989, pp. 1-32, https://doi.org/10.1007/978-3-642-74069-5_1

10 B. J. Zobel and J. R. Sprague, in "Juvenile Wood", Springer, Berlin, Heidelberg, 1998, pp. 141-172, https://doi.org/ 10.1007/978-3-642-72126$7+5$

${ }^{11}$ V. A. Alfonso, P. Baas, S. Carlquist, J. P. Chimelo, V. T. Rauber Coradin et al., IAWA J., 10, 221 (1989), https://www.iawa-website.org/

12 S. E. Ruzin, in "Plant Microtechnique and Microscopy", Wiley-Blackwell, Oxfort, UK, 1999, https://doi.org/10.1046/j.1469-8137.2000.00735.x

13 ASTM (American Society for Testing and Materials), ASTM D-110-13 (2016), https://doi.org/10.1520/D1110-84R13

14 TAPPI (American Paper \& Pulp Association), Tappi Standard T 222 om-0, (2002), https://www.tappi.org/

15 K. Seifert, Das Pap., 14, 104 (1960)

16 ASTM (American Society for Testing and Materials) ASTM D-111 (2016), https://doi.org/10.1520/D1110-84R13

17 ASTM (American Society for Testing and Materials), ASTM D 1109-84 (2016), https://doi.org/10.1520/D1109-84R13

18 ASTM (American Society for Testing and Materials), ASTM D1107-96 (2013), https://doi.org/10.1520/D1107-96R13

19 ASTM (American Society for Testing and 
Materials),

ASTM

D1102-84, https://doi.org/10.1520/D1102-84R13

20 ASTM (American Society for Testing and Materials), ASTM D5865-13 (2013), https://doi.org/10.1520/D5865-13

21 R. Hess, F. Wangaard and F. Dickinson, Trop. Woods, 197, 1 (1950), http://www.iawawebsite.org/uploads/soft/download/tropical_woods/ Tropical\%20Woods\%201949_95.pdf

22 D. Woodcock and A. Shier, Trees - Struct. Funct., 16, 437 (2002), https://doi.org/10.1007/s00468-002-0173-7

23 R. Moya and F. Muñoz, J. Trop. For. Sci., 22, 317 (2010), https://www.jstor.org/stable/23616661

24 C. Tenorio, C. Salas and R. Moya, Dry. Technol., 34, 343 (2014), https://doi.org/10.1080/07373937.2015.1060493

25 C. L. S. Mori, F. A. Mori, L. M. Mendes and J. R. M. Silva, Bras. Florest., 1, 29 (2003), https://www.brasilflorestal.com/

${ }^{26}$ S. Pfautsch, M. J. Aspinwall, J. E. Drake, L. Chacon-Doria, R. J. A. Langelaan et al., Ann. Bot., 121, 129

(2018), https://doi.org/10.1093/aob/mcx137

27 A. M. Taylor, B. L. Gartner and J. J. Morrell, Wood Fiber Sci., 34, $587 \quad$ (2002), https://wfs.swst.org/index.php/wfs/article/view/539

28 C. E. T. Paine, C. Stahl, E. A. Courtois, S. Patiño, C. Sarmiento et al., Funct. Ecol., 24, 1202 (2010), https://doi.org/10.1111/j.1365-
29

Bosque 37,

C. Salas and A. Berrocal, $71 \quad$ (2016) https://doi.org/10.4067/S0717-92002016000100008 30 M. Larjavaara and H. C. Muller-Landau, Funct. Ecol., $\quad$ 24, $701 \quad$ (2010), https://doi.org/10.1111/j.1365-2435.2010.01698.x

${ }_{31}$ P. Hietz, R. Valencia and S. Joseph Wright, Funct. Ecol., 27, $684 \quad$ (2013), https://doi.org/10.1111/1365-2435.12085

32 O. L. Osazuwa-Peters, S. J. Wright and A. E. Zanne, Am. J. Bot., 101, 803 (2014), https://doi.org/10.3732/ajb.1400040

${ }_{33}$ H. T. Hegde, M. A. Kalkoor, S. K. Jha and N. S. Thakur, Indian For., 140, 70 (2014), http://www.indianforester.in/index.php/indianforest er/article/view/45940

34 S. Koman and S. Feher, Eur. J. Wood Wood Prod., $\quad 78, \quad 421 \quad$ (2020), https://doi.org/10.1007/s00107-020-01497-x

35 T. Sedlar, B. Šefc, D. Drvodelić, B. Jambreković, M. Kučinić et al., Drv. Ind., 71, 179 (2020), https://doi.org/10.5552/drvind.2020.1964

36 M. Beel, S. Davis, J. Murphy and P. Piper, Aust. For., $\quad$ 68, $\quad 3 \quad$ (2005), https://doi.org/10.1080/00049158.2005.10676219

37 S. V. Vassilev, D. Baxter, L. K. Andersen and C. G. Vassileva, Fuel, 89, 913 (2010), https://doi.org/10.1016/j.fuel.2009.10.022

38 R. Moya, C. Tenorio, J. Salas, A. Berrocal and F. Muñoz, in "Tecnología de la madera de plantaciones forestales" [Forest Plantation Wood Technology], Costa Rica University Press, Cartago, Costa Rica, 2019 